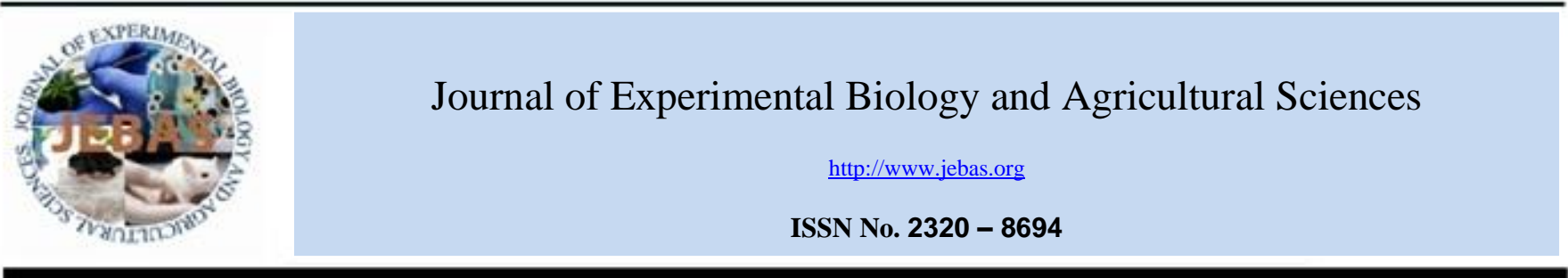

\title{
FARM LEVEL AND AGGREGATE ECONOMIC IMPACT OF DIRECT SEEDED RICE IN PUNJAB
}

\author{
Nirmala Bandumula $^{1}$, Gulshan Mahajan ${ }^{2}$, R.Mahender Kumar ${ }^{1}$
} ${ }^{1}$ ICAR-Indian Institute of Rice Research, Hyderabad, India.
${ }^{2}$ The Centre for Plant Science, Queensland Alliance for Agriculture and Food Innovation (QAAFI), The University of Queensland, Gatton/Toowoomba, Queensland,
Australia.

Received - November 08, 2017; Revision - December 18, 2017; Accepted - February 13, 2018

Available Online - February 20, 2018

DOI: http://dx.doi.org/10.18006/2018.6(1).253.257

\section{KEYWORDS \\ Direct seeded rice \\ Transplanted rice \\ Cost}

Punjab

\section{* Corresponding author}

E-mail: bnirmaladrr@gmail.com, Nirmala.B@icar.gov.in (Nirmala Bandumula)

Peer review under responsibility of Journal of Experimental Biology and Agricultural Sciences.

Production and Hosting by Horizon Publisher India [HPI] (http://www.horizonpublisherindia.in/).

All rights reserved.

\begin{abstract}
The essence of agricultural development is to improve both individual farm household welfare and in the aggregate, achieve desirable economic and social impacts. Despite the availability of literature on the farm level impact of DSR, few studies have attempted to measure the aggregate effects of adoption of DSR at the state level. A survey was conducted during 2015, comprising 150 randomly selected farmers covering three major direct seeded rice districts viz., Sri Muktsar Sahib, Bathinda and Kapurthala of Punjab state of India to understand the farm level and aggregate economic impact of DSR in Punjab. The results showed that the adoption of DSR has reduced the cost of cultivation by about $29 \%$ on an average. At the aggregate level, potential benefits from the adoption of DSR are substantial. The survey results reveal that adoption of DSR has resulted in lowering cost of cultivation of rice by Rs. 14,615/- per hectare over the transplanting method. The aggregate monetary benefits in terms of savings in cost of cultivation by adoption of DSR to the adopter farmers in Punjab is estimated to the tune of Rs.730,750,000 for the year 2015. The findings confirm the positive impacts of DSR and the results support promoting DSR as a strategy to enhance profitability of farmers and also as a water saving technology in the face of depleting water resources for agriculture in general and rice in particular.
\end{abstract}

All the article published by Journal of Experimental Biology and Agricultural Sciences is licensed under a Creative Commons Attribution-NonCommercial 4.0 International License Based on a work at www.jebas.org.

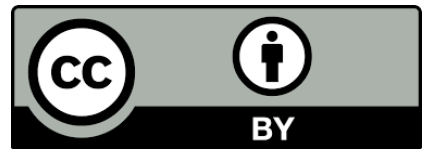




\section{Introduction}

Rice is one of the most important food crops of India. It occupies highest area among all the crops grown in the country. Rice production accounted for 44.5 percent of total cereal production and 41 percent of total food grain production in 2014-15 (State of Indian Agriculture, 2015-16). The area during 1951-52 was $30 \mathrm{~m}$ ha and it has reached to 43 million hectare in 2016-17. The rice production has registered an appreciable increase from $21 \mathrm{MT}$ in 1950-51 to over $100 \mathrm{MT}$, which is nearly 5 times over the production in 1950s. The production has set the highest record of 109 million tonnes in 2016-17 ( $2^{\text {nd }}$ advance estimates, Government of India, 2017).

Water scarcity is becoming a major concern for the productivity and sustainability of the rice cultivation. Transplanting is the most adopted method of rice establishment in India. The transplanted puddled rice (TPR), leads to higher losses of water through puddling, surface evaporation and percolation (Farooq et al., 2011).

The traditional transplanting method of rice cultivation involving puddling of the soil, adversely affects the soil structure by disturbing the soil aggregates, reducing the soil permeability and creating hardpans at shallow depths (Sharma et al., 2003), all of which have adverse affect on the following crop (Tripathi et al., 2005). The water and labour scarcity is driving the farmers to shift from traditional transplanting method to Direct Seeded Rice (DSR). In Asia, due to depleting water resources and scarcity of labour, adoption of DSR is gaining momentum (Rakesh et al., 2017).

In Direct Seeded Rice (DSR), seeds are sown before or immediately after pre-monsoon rain (Kakumanu et al., 2011). Transplanting method of rice cultivation involves three basic operations, namely, puddling (a process where soil is compacted to reduce water seepage), transplanting and maintaining standing water (Joshi et al., 2013). These three operations can be avoided with the adoption of DSR. Direct seeding is of two types (1) WetDSR, in which, on puddled soil, sprouted rice seeds are broadcast or sown in lines, and (2) Dry-DSR, in which, after dry tillage or zero tillage, dry rice seeds are drilled or broadcast on unpuddled soil.

In India, Punjab State has been playing a leading role in the agricultural transformation of the country (Mahajan et al., 2015). A sustainable production of rice in Punjab is crucial for the food security of India. Currently, out of 20 million tube wells in the country, almost 1.3 million are in Punjab, contributing to fastpaced groundwater extraction and its depletion (Satvir \& Vatta, 2015). Due to the depleting ground water resources, the irrigation expenditure for rice crop has increased significantly in the last decade (Sidhu \& Vatta, 2006). Though puddled transplanted rice is the most popular system but whether under the emerging scenario of acute shortages of water and labor, it would maintain sustainability in future is highly uncertain (Mahajan et al., 2011a; Mahajan et al., 2011b).

The essence of agricultural development is to improve both individual farm household welfare and in the aggregate, achieve desirable economic and social impacts (Menale et al., 2016). Despite the availability of literature on the farm level impact of DSR, few studies have attempted to measure the aggregate effects of adoption of DSR at the state level. An attempt has been made to measure both the farm level and aggregate economic impact of DSR in Punjab.

Punjab has 5.03 million hectare geographical area, out of which 4.23 million hectare is under cultivation. About $75 \%$ of its population depends directly on agriculture. Rice was grown on an area of 2.9 million hectare with a production of 17.6 million tons during the year 2014-15 (Department of Agriculture, Government of Punjab, 2017). The State of Punjab has been classified into five agro-climatic zones on the basis of homogeneity, rainfall pattern, distribution, soil texture, cropping pattern. These zones are Submountain undulating zone (I), Undulating plain zone (II), Central plain zone (III), Western plain zone (IV) and Western Zone (V).

DSR is popular in Central Plain (III) and Western (V) Zones of Punjab. The main reason for adoption of DSR in these zones was that the agroecology is favorable for the cultivation of DSR. In Zone III, the water table is very deep ( $>25 \mathrm{~m})$. This region, being an industrial centre of the state, has a shortage of labor and wages are high, which hinders the continued cultivation of Puddled Transplanted Rice (PTR). Therefore, DSR, which has proven benefits of reduced water and labour requirements and less risk of cracking of soil under limited water supply, in comparison with the PTR, is attracting farmers in this Zone. In Zone V, water scarcity is one of the reasons farmers are attracted toward DSR (Mahajan et al., 2013). Hence, Kapurthala distrtict of Central Plain Zone (III) and Sri Muktsar Sahib and Bathinda districts of Western (V) Zones of Punjab were selected for the study.

In the scenario of fast paced depletion of ground water in Punjab and intensive cultivation of rice involving high amount of water use which may result in adverse effects on water table, there is an urgent need to shift from traditional transplanting method of rice cultivation to DSR, as DSR tends to reduce water consumption, labour requirement and helps to maintain the soil structure. In this backdrop, the present paper, therefore, attempts to examine the farm level and aggregate economic impact of Direct Seeded Rice in Punjab. 


\section{Materials and Methods}

The data for this study are derived from focus group discussions and household survey conducted in 2015 . The primary data were collected using pretested questionnaire. Data were collected from 150 rice farmers of three major Direct Seeded Rice districts viz., Sri Muktsar Sahib, Bathinda and Kapurthala of Punjab state. Of the 150 rice growers interviewed, $42 \%$ were from Sri Muktsar Sahib district, $33 \%$ were from Bathinda district and $25 \%$ were from Kapurthala district. These districts were purposively selected for the study as DSR has been widely adopted there because of favourable agro-ecology for adoption of DSR. The total costs and returns in Direct seeded rice and transplanted rice were compared. Productivity, costs and income between DSR and transplanted rice cultivation were compared. The income of farmers per hectare was computed from the difference between revenue (yield $\times$ price per $\mathrm{kg}$ ) and paid-out costs (cash costs).

The total effect of adoption of Direct Seeded Rice (DSR) at state level for the state of Punjab in terms of monetary benefits to the adopter farmers was worked out by using Meredia's Framework. The goal in performing an impact analysis of a technological innovation or intervention is to estimate the total effect of the new technology on some set of outcome variables, after some amount of diffusion has taken place (Maredia, 2009, Maredia \& Raitzer, 2012). Meredia laid out the steps pursued by existing impact evaluations to estimate the total effect of a new technology on a set of outcome variables after some amount of diffusion has taken place. In Meredia's framework, two key quantities must be estimated in order to arrive at the total impact of a new technology: the extent of adoption (Ec) and the average effect that adoption has on outcomes for those who have adopted (Es) (Alain et al., 2010). An important technological change that increases the domestic production of a crop may not induce price changes if the country is open to imports and exports. In these cases, the aggregate effect of the technology may be measured by the simple product $E s \times E c$ provided that the estimated effect size $E s$ corresponds to the estimated area of adoption $E c$.

The estimates of extent of adoption of DSR were obtained from secondary sources and through interaction with the agriculture officers of Punjab. The average effect of the adoption of DSR on those who have adopted (Es), in terms of farm level impact, has been estimated from the survey results. The priority Index for each variable was calculated by using formula of Miah (1993)

I prob $=\sum \frac{\text { Sifi }}{\mathrm{N}}$

Where,

I prob Index value for intensity of problem

$\sum$ Summation

$\mathrm{S}_{\mathrm{i}}$ Scale value of $\mathrm{i}^{\text {th }}$ intensity $f_{i}$ Frequency of $i^{\text {th }}$ respondent

$\mathrm{N}$ Total number of respondents

\section{Results and Discussion}

The major varieties used by the farmers in the study area are Pusa Basmati 1121, PR 122, PR 114, PR 118, P 44 and PR 111. The results indicated that the mean area allocated to cultivation of DSR and transplanted rice was 1.9 hectares and 2.9 ha respectively. The smaller area allocated to DSR is assumed to be due, at least partly, to farmers risk management in dealing with a relatively new technology.

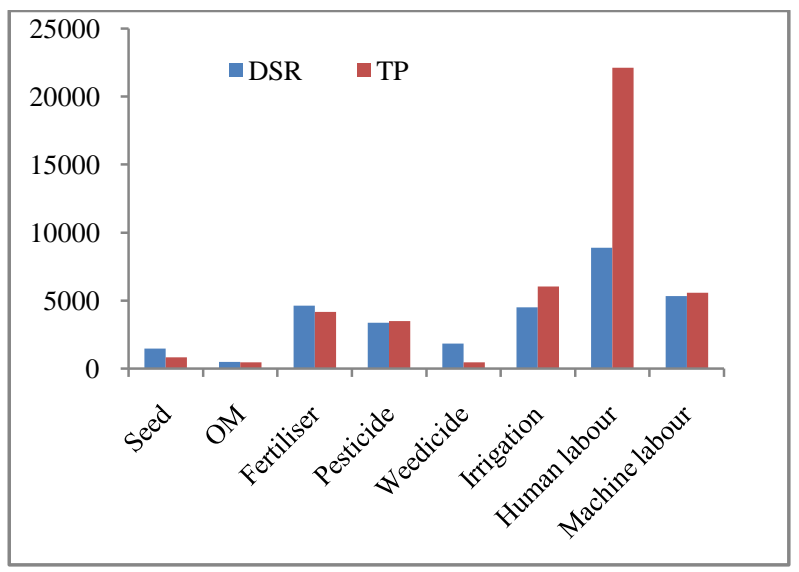

Figure 1 Comparison of costs in DSR and transplanted method (per ha)

A comparison of the costs in DSR and transplanted method of rice cultivation in the study area, are presented in Figure 1. The DSR farmers used $10.75 \mathrm{kgha}^{-1}$ more seed as compared to transplanted rice and is significant at $0.5 \%$. The main reason for using higher seeding rate in DSR is the fact that DSR requires higher seed rate than the transplanted method and also partly because of the fear of the farmers about the seed rotting which may occur due to rain after sowing. The labor costs for weeding were significantly higher for DSR than the transplanting method. This is due to combined effect of applying more herbicides and manual labor for weed management under DSR method of rice cultivation. Adoption of DSR has resulted in saving on irrigations to the tune of $25 \%$ over the transplanted method.

The farmers opined that the adoption of DSR has resulted in obtaining slightly higher yield than the transplanting method (Table 1), which may be because of good weed management practices and this concurs with the study of Johnson et al. (2003). Neeraj et al. (2012) also reported higher yields in DSR, which may be because of timely sowing of paddy and effective weed management. A reduction in cost of cultivation to the tune of Rs.12,621/- per hectare was reported with the adoption of DSR. 
These reduced costs were mainly due to the reduction in labour required for crop establishment with direct-seeding. Similar results were reported by Arelene et al., (2014). The net returns were Rs. 56,283/- per hectare for DSR and Rs. 41,668/- per hectare for transplanting method.

The difference in income is positive and significant indicating that the DSR farmers could earn more than the transplanting method of rice cultivation. The net returns and $\mathrm{B}: \mathrm{C}$ ratio were higher in DSR because of lower cost of cultivation as compared to transplanted method of rice cultivation. Adoption of DSR has resulted in savings to the tune of Rs.14,615 per hectare in comparison to the transplanted rice. These results corroborate with the findings of Chandrasekhara et al. (2013), who reported that adoption of direct seeding in rice will reduce the labour requirement, increase the yield by $8-11 \%$ and reduce the cost of cultivation.

Farmers' perception to advantages and constraints of DSR and conventional transplanted rice were ranked by using five point scales of variables comprising most, relatively more, moderate, modest and not at all using scores of 1.00, 0.75, 0.5 and 0.25 and 0 respectively.

Rank order index showed that coping with labor shortage due to avoidance of transplanting was the strength of DSR followed by lower number of irrigations required for DSR (Table 2). Lower costs of cultivation, more wheat yields (when wheat is grown as a subsequent crop to DSR rice) and less wear and tear of the machinery used in rice cultivation were the main strengths as reported by the survey farmers. The main constraint in DSR was weed management followed by difficulty in crop establishment (Table 3). The farmers reported that fertilizer management is comparatively difficult in DSR than the transplanting method. Rat menace and crop damage due to disease and pest infestation were the other constraints in DSR as reported by the survey farmers.

\subsection{Aggregate impact of DSR on profitability of rice farmers in Punjab}

Yield is a measure of impact but may not reveal the extent of the producer's welfare affected by the technology. Hence farm level profits are the natural place to start when looking for immediate impacts of a technology. DSR was adopted on an area of 50,000 hectares in Punjab in the year 2015. The survey results reveal that adoption of DSR has resulted in lowering cost of cultivation of rice by Rs. 14,615 per hectare over the transplanting method (Table 1). The total impact of direct seeded rice was calculated based on the extent of adoption (Ec, 50,000 ha) and the average effect that adoption has on outcomes for those who have adopted (Es, Rs. 14,615/ha). The aggregate effect of the technology may be measured by the simple product $E s \times E c$ provided that the
Table 1 Comparative Economics of DSR vs Transplanted method

\begin{tabular}{|cccc|}
\hline Sl.No. & Particulars & DSR & $\begin{array}{c}\text { Transplanted } \\
\text { method }\end{array}$ \\
\hline 1 & Yield (Qt1/ha) & 5.4 & 5.27 \\
\hline 2 & $\begin{array}{c}\text { Gross Returns } \\
\text { (Rs./ha) }\end{array}$ & 86795 & 84800 \\
\hline 3 & $\begin{array}{c}\text { Cost of cultivation } \\
\text { (Rs./ha) }\end{array}$ & 30511 & 43132 \\
\hline 4 & Net Returns (Rs./ha) & 56283 & 41668 \\
\hline 5 & BC Ratio & 2.84 & 1.97 \\
\hline
\end{tabular}

Table 2 Merits of DSR

\begin{tabular}{|cccc|}
\hline Sl.No. & Advantages & Index & Rank \\
\hline 1 & $\begin{array}{c}\text { Reduced labour } \\
\text { requirement }\end{array}$ & 0.86 & I \\
\hline 2 & $\begin{array}{c}\text { Lower number of } \\
\text { irrigations }\end{array}$ & 0.72 & II \\
\hline 3 & $\begin{array}{c}\text { Reduced cost of } \\
\text { cultivation }\end{array}$ & 0.67 & III \\
\hline 4 & $\begin{array}{c}\text { Less wear and tear of } \\
\text { machinery }\end{array}$ & 0.42 & IV \\
\hline 5 & More wheat yields & 0.33 & V \\
\hline
\end{tabular}

Table 3 Constraints in adoption of DSR

\begin{tabular}{|cccc|}
\hline Sl.No. & Constraints & Index & Rank \\
\hline 1 & Weed Management & 0.92 & I \\
\hline 2 & $\begin{array}{c}\text { Poor crop } \\
\text { establishment }\end{array}$ & 0.84 & II \\
\hline 3 & $\begin{array}{c}\text { Difficulty in Fertiliser } \\
\text { management }\end{array}$ & 0.76 & III \\
\hline 4 & $\begin{array}{c}\text { Problem of voluntary } \\
\text { plants }\end{array}$ & 0.52 & IV \\
\hline 5 & $\begin{array}{c}\text { Pest and disease } \\
\text { incidence }\end{array}$ & 0.48 & V \\
\hline
\end{tabular}

estimated effect size Es corresponds to the estimated area of adoption Ec. The aggregate monetary benefits in terms of additional net returns by adoption of DSR in Punjab is estimated to the tune of Rs.730,750,000 for the year 2015.

\section{Conclusion}

The results showed that the adoption of DSR has reduced the cost of cultivation by 29 per cent on an average. The farmers who adopted DSR received higher profits in comparison with the conventional transplanted rice cultivation, because of reduced labour costs for crop establishment and also higher yields obtained in DSR. Also, adoption of DSR has allowed an earlier 
harvest of the crop. At the aggregate level, potential benefits from the adoption of DSR are substantial. The findings confirm the positive impacts of DSR and the results support promoting DSR as a strategy to enhance profitability of farmers and also as a water saving technology in the face of depleting water resources for agriculture in general and rice in particular.

\section{References}

Alain DJ, Andrew D, Elisabeth S (2010) Recent Advances in Impact Analysis Methods for Ex-post Impact Assessments of Agricultural Technology: Options for the CGIAR, Prepared for the workshop "Increasing the rigor of ex-post impact assessment of agricultural research: A discussion on estimating treatment effects", organized by the CGIAR Standing Panel on Impact Assessment, SPIA, on October 2, 2010, Berkeley.

Chandrasekhararao C, Jitendranath S, Murthy TGK (2013) Resource Optimisation in Rice through Direct Seeding by Drum Seeder. International Journal of Agriculture and Food Science Technology 4: 239-246

Department of Agriculture, Govt. of Punjab, 2017. Available on http://agripb.gov.in/agri_statistics/pdf/Year\%20Cropwise\%20AY P\%202001\%20to\%20onward..pdf access on 22.09.2017.

Farooq M, Siddique KHM, Rehman H, Aziz T, Dong-Jin L, Wahid A (2011) Rice direct seeding: Experiences, challenges and opportunities. Soil Tillage Research 111: 87-98.

Johnson D, Mortimer M, Orr A, Riches C (2003) Weeds, rice and poor people in South Asia. Chatam: Natural Resources Institute.

Joshi E, Dinesh KBL, Nepalia V, Priyanka G, Vyas AK (2013) Management of Direct Seeded Rice for enhanced resource use efficiency. Plant Knowledge Journal 2: 119-134.

Kakumanu KRK, Gurava R, Palanisami K, Udayasekhar N, Lakshmanan A, Tulasi J (2011) Adaptation of Direct Seeded Rice under Water stress conditions in Andhra Pradesh, CLIMA RICE II: "Sustaining Rice Production in A Changing Climate". Technical brief \#7. International Water Management Institute.

Mahajan G, Chauhan BS, Gill MS (2011a) Optimal N fertilization timing and rate in dry-seeded rice in northwest India. Agronomy Journal 103:1676-1682.

Mahajan G, Timsina J, Singh K (2011b) Performance and water use efficiency of rice relative to establishment methods in northwestern Indo-Gangetic Plains. Journal of Crop Improvement 25:597-617

Mahajan G, Chouhan BS, Gill MS (2013) Dry-seeded rice culture in Punjab State of India: Lessons learned from farmers. Field Crops Research 144: 89-99.

Mahajan G, Sharma R, Kaur R, Chauhan BS (2015) Comparison of photoperiod-sensitive and photoperiod-insensitive basmati cultivars for grain yield, water productivity and quality traits under varied transplanting dates in Northwest India. Crop Pasture Science 66: 793-801.
Maredia MK (2009) Improving the Proof: Evolution of and Emerging Trends in Impact Assessment Methods and Approaches in Agricultural Development. IFPRI Discussion Paper no. 00929, IFPRI, Washington, D.C.

Maredia MK, Raitzer DA (2012) Review and analysis of documented patterns of agricultural research impacts in Southeast Asia. Agricultural Systems 106:46-58.

DOI: 10.1016/ j.agsy.2011.10.011

Menale K, Yohannis T, Paswel M, Di Z, Moti J, Olaf E (2016) Measuring farm-level and aggregate economic impacts of improved maize production technologies in Ethiopia: Evidence from panel data, Paper presented in 'African Economic Conference' held at Nigeria during 5-7 December 2016.

Miah AQM (1993) Applied Statistics: A Course Handbook for Human Settlements Planning, Studies on Human Settlement Development in Asia, HSD Reference Materials, 24, Human Settlement Division, Asian Institute of Technology, Thailand, Pp. 316-320.

Neeraj SN, Singh B, Rai AB, Dubey AK, Ashok R (2012) Impact of Direct seeded rice (DSR) for resource conservation. Indian Research Journal of Extension Education, Special Issue (Volume II): 6-9.

Press Information Bureau, Ministry of Agriculture, Government of India. $2^{\text {nd }}$ Advance estimates of production of major crops for 2016-17. Available on http://pib.nic.in/newsite/PrintRelease.aspx? relid $=158478$ access on 22.09.2017.

Rakesh S, Mahajan G, Mukesh S, Angrej S, Chauhan BS ( 2017) Performance of drip-irrigated dry-seeded rice (Oryza sativa L.) in South Asia. Paddy Water Environment 15:93-100.

Satvir K, Vatta K (2015) Groundwater depletion in Central Punjab: pattern, access and adaptations. Current Science 108: 25 485-490

Sharma PK, Ladha JK, Bhushan L (2003) Soil physical effects of puddling in rice-wheat cropping systems. In: Ladha JK, Hill JE, Duxbury JM, Gupta RK, Buresh RJ (Eds.), Improving the Productivity and Sustainability of Rice-Wheat Systems: Issues and Impacts, ASA, CSSA, SSSA, Madison, WI, ASA, Special Publication 65: 97- 113.

Sidhu RS, Vatta K (2006) Economic implications of groundwater resources degradation and its management strategies in Punjab agriculture. Journal of Agricultural Development and Policy 18: 50-59.

State of Indian Agriculture (2015-16) Ministry of Agriculture, Government of India.

Tripathi RP, Sharma P, Singh S (2005) Tillage index: An approach to optimize tillage in rice-wheat system. Soil and Tillage Research 80:125-137. 